\title{
CORRELATION BETWEEN CONSUMPTION OF VITAMIN A ON POSTPARTUM MOTHER AND BREAST MILK ADEQUACY
}

\author{
Icha Berliana ${ }^{1)}$; Munayarokh'); Siti Rofi'ah ${ }^{3)}$ \\ ichaberliana996@gmail.com \\ Health Polytechnic of Semarang \\ Midwifery Bachelor Study Program of Magelang
}

\begin{abstract}
Background: Supplementation of vitamin A for postpartum mothers is needed to increase the amount of vitamin A in breast milk. Babies who suck the breast milk that contains enough vitamin A will be more immune and rarely suffered from infectious diseases.

Purpose: The study aimed to determine the association of vitamin A consumption in postpartum mothers with adequacy of breast milk.

Methods: This study is an analytical survey with cross-sectional design approach, condected within the work area of Mungkid Community Health Center, Magelang Regency with total sampling. The sample were 40 respondents. The data was retrieved by using a checklist observation sheet.

Result: Statistical analysis with Spearman Rank test, obtained p-value of 0.000 so that $<0.05$, which means there was a significant relationship between consumption of vitamin A in postpartum mothers with adequate breastfeeding.

Concluslion: Consumption of vitamin A in postpartum mothers correlated with breast milk adequacy. Midwives are expected to provide health care and health education, regarding vitamin A for postpartum women, and give 2 capsules of vitamin A to the mother after delivery. Postpartum mothers are suggested to obtain and consume 2 capsules of vitamin A after giving birth, because the benefits are many, especially with the adequacy of breast milk.
\end{abstract}

Keywords : postpartum, vitamin A, adequacy of breast milk

1) Student at the Midwifery Bachelor Study Program Magelang of Health Polytechnic Of Semarang

2,3) Lecturer at the Midwifery Bachelor Study Program Of Magelang of Health Polytechnic Of Semarang

Background. Vitamin $\mathrm{A}$ is an essential substance to improve the body's resistance to infection for the growth of tissue cells for healthy skin, teeth, and bone tissue, as well as the development of the visual nerve. The puerperal period should be given vitamin A to increase the amount of content of vitamin A in breast milk and the mother's health quickly recovered after giving birth. Besides useful for puerperal women, vitamin
$A$ is also beneficial in infants, because the mothers breastfeed their babies during childbirth thus indirectly also getting it. the baby was breastfed that contains enough vitamin A will be immune and infectious diseases rarely.

Vitamin A deficiency is widely available in developing countries, including Indonesia, because foods rich in Vitamin A is generally expensive. One of the earliest 
Vitamin A deficiency is night blindness, the inability of the eye to adjust the vision of bright light and vague / dusk. Consumption of Vitamin A that is not enough deposits in the body cause thinning thus reducing blood levels of vitamin A, which resulted in the eye's retina are not obtaining enough Vitamin A to form the visual pigment/rhodopsin (Almatsier, 2010). Decreased immune function in a deficiency of vitamin A, so susceptible to disease infection. Besides, a layer of cells that covers the trachea and lungs keratinized, no mucus, making it easy to enter microorganisms or bacteria or viruses causing respiratory infections. When present on the surface of the intestinal wall will cause diarrhea. Also, vitamin A deficiency in children can cause complications from measles can lead to death(Adriani \& Wijatmadi, 2012).

RI (2009) explain that postpartum mothers have given high doses of vitamin A to increase the content of vitamin A in breast milk to infants aged 6 months. According to Almatsier (2010) vitamin A effect on protein synthesis, and the effect on cell growth. Vitamin A is needed for bone development and forms email epithelial cells in the dentition, therefore, Vitamin A supplementation in postpartum mothers is needed.

According to Bina, Nutrition, and Department (2009) the number of maternity coverage in the health care facility in Indonesia in 2017, namely $83.67 \%$ of the target of $100 \%$ coverage. Data Central Java Health Office in 2017 showed that the number of postpartum mothers who received vitamin A supplementation in Central Java province that is equal to $97.46 \%$ of the target of $100 \%$ coverage, and in the districts of
Magelang is equal to $99.50 \%$ of the target of $100 \%$ coverage, Magelang District Health Office Data 2016 shows the number of postpartum mothers who received vitamin A supplementation in the clinic Mungkid already high at $98.4 \%$ of the target of $100 \%$ coverage.

In the puerperal period should be given vitamin $\mathrm{A}$ to increase the amount of vitamin A content in breastmilk addition to maternal vitamin $\mathrm{A}$ is also beneficial in infants, because the mothers breastfeed their babies during childbirth thus indirectly the baby was also getting it. Benefits of vitamin $\mathrm{A}$ in addition to increasing endurance can also improve child survival and help the recovery of postpartum maternal health are closely related to anemia and reduce the risk of blindness in nursing mothers (Saleha, 2009). Vitamin A is used for cell growth tissue, teeth, bones, the development of visual nerve, increase endurance before infection.

Giving vitamin A postpartum mothers is one of the early containment of the deficiency of vitamin A. The program aims to maintain the levels of serum retinol in the blood and breast milk. Breast milk is the primary source of vitamin A, which is used to protect children against disease xerophthalmia(Gibney, 2009). Vitamin A supplementation for postpartum mothers can increase the amount of content of Vitamin A in breast milk, so supplementation of vitamin A $(200,000$ units $)$ in postpartum mothers is very important. Benefits of vitamin $\mathrm{A}$ in addition to increasing endurance can also improve child survival and maternal health aid recovery postpartum. This 
is because vitamin A serves to help produce steroid (Almatsier, 2010)

Preliminary studies have been conducted in Puskesmas Mungkid Magelang. After the authors conducted interviews in the village Bumirejo (one village included Puskesmas Mungkid) to 10 puerperal women about vitamin A for mothers postpartum, showed 6 puerperal women $(60 \%)$ received and vitamin A, 4 postpartum mothers $(40 \%)$ did not receive and did not consume vitamin A for women giving birth in hospitals and did not get vitamin A from the hospital or midwife. Besides, researchers also conducted interviews directly to 10 puerperal women, obtained the following results, there are 6 out of 10 respondents did not know about the benefits of vitamin A supplementation on postpartum mothers, the benefits of vitamin A of the adequacy of breast milk to the baby.

Purpose. This study was aimed to find correlation between consumption of vitamin A in postpartum mothers and breast milk adequacy.

Method. This study is an analytical survey in Puskesmas Mungkid Magelang District at February 2019. The population in this study were postpartum mothers within working area of Puskesmas Mungkid Magelang District in March 2019 as many as 45 respondents. A total sampling method was use, in which all members of the population were used as a sample (Notoatmodjo, 2014), Samples in this study there were 40 respondents, postpartum mothers who consume 2 capsules of vitamin A after delivery and only give breast milk to her baby. The research instrument used in this study is a checklist sheet to measure the adequacy of breast milk by observing the babies for the sign of enough milk. Univariate analysis aims to explain or describe the characteristics of each of the variables. Rank Spearman statistical test with $\mathrm{p}$ value $<0.05$ was set.

\section{Result And Discussions}

\section{A. Consumption of vitamin $A$ in postpartum mothers}

Table 1 Consumption of Vitamin A

\begin{tabular}{llc}
\hline Consumption of Vitamin A & Freq & $\%$ \\
\hline 2 capsules of vitamin A & 30 & $75 \%$ \\
1 capsule of vitamin A & 10 & $25 \%$ \\
& 40 & $100 \%$ \\
\hline
\end{tabular}

As seen in table 1 that more postpartum mothers consume 2 capsules of vitamin A as many as 30 respondents (75\%). Partum mothers who consume 2 capsules of vitamin A after giving birth can increase the adequacy of breastfeeding and baby's immune system. This is similar to research (Greetings, Dodik, Martianto, Ansul, \& Arundhana, 2018) that one of the immediate effects of influence of supplementation of high doses of vitamin $\mathrm{A}$ is the changing levels of vitamin $\mathrm{A}$ in breast milk, which contain enough vitamin $\mathrm{A}$ in breast milk may provide protection to infants against disease infeksi.Bagi postpartum mothers are expected to obtain and consume 2 capsules vitamin A while after giving birth, because the benefits are many, especially with the adequacy of breast milk to her baby.

B. Adequacy of breast milk

Table 2 Breast milk Adequacy

\begin{tabular}{lcc}
\hline $\begin{array}{c}\text { Adequacy of } \\
\text { breast milk }\end{array}$ & Freq & $\%$ \\
\hline Enough & 26 & $65 \%$ \\
Less & 14 & $35 \%$ \\
& 40 & $100 \%$ \\
\hline
\end{tabular}


Adequacy of breast milk in this study can be seen from table 2 that more babies are getting enough as many as 26 people or $65 \%$. Most of the respondents have less breast milk adequacy at 5 points, namely, the breast feels softer, which signifies the milk had expired and in point 9 that baby seems satisfied, at any time during waking and sleep hungry enough.

A total of 26 babies have sufficient enough milk after postpartum mothers consume 2 capsules of vitamin A. Breast milk (ASI) is the best life fluid that is needed by the baby. Breast milk contains many substances that are important for the growth and development of infants and by their needs. Breast milk production and expenditure is influenced by two hormones, prolactin, and oxytocin. Prolactin affects the processing of milk. Prolactin related to maternal nutrition, the intake of good nutrition, the production generated too much.

This study is similar to research (Usman, 2019) entitled Combination Methods Woolwich and Massage Rolling Massage (back) Affects Breastfeeding On Capital Adequacy postpartum in Puskesmas Mapane Poso district, stating that the action rolling back massage can affect the hormone prolactin, which serves as a stimulus for milk production in lactating mothers. It can also relax the mother and flow nerves and milk ducts in the breast. Purpose Massage Woolwich has triggered stimulation myoepithelial cells around the breast gland, then stimulation is headed to the hypothalamus and anterior pituitary can lead to producing hormones prolactin. ASI expenditure is influenced by two hormones, prolactin, and oxytocin. Prolactin affects the amount of milk production, while oxytocin affects breastfeeding expenditure.

C. Relations between consumption of vitamin A on the adequacy of postpartum mothers with breast feeding infants

Spearman Rank test resulting in p-value of 0.000 to $<0.05$, which means that there is a relationship between consumption of vitamin A in postpartum women and breast milk adequacy

Table 3 Consumption of Vitamin

A Relationship On Postpartum Mothers with Breastmilk Adequacy

\begin{tabular}{lllll}
\hline \multirow{2}{*}{$\begin{array}{l}\text { Consumption } \\
\text { vitamin A }\end{array}$} & \multicolumn{2}{c}{$\begin{array}{c}\text { Breast } \\
\text { adequacy }\end{array}$} & Total \\
& & Less & Enough & \\
\hline 1 capsule & $\mathrm{F}$ & 10 & 0 & \\
\cline { 2 - 5 } & $\%$ & $100 \%$ & $0 \%$ & $100 \%$ \\
\hline 2 capsules & $\mathrm{F}$ & 4 & 26 & \\
\cline { 2 - 5 } & $\%$ & $13.3 \%$ & $86.7 \%$ & $100 \%$ \\
\hline $\mathrm{P}$ value & 0,000 & & & \\
\hline
\end{tabular}

The breast milk adequacy of respondents with enough milk and consume 2 capsules of vitamin $\mathrm{A}$ is $86.7 \%$ more compared to those consuming 1 capsule of vitamin A which was $0 \%$. While the breast milk adequacy of respondents with less milk and consume one capsule of vitamin A more $100 \%$ compared to those consuming 2 capsules of vitamin A which was $13.3 \%$. Thus the more the consumption of vitamin $\mathrm{A}$ is getting enough milk for her baby.

The results show that there is no association between the consumption of vitamin $\mathrm{A}$ on the 
adequacy of postpartum mothers with breastfeeding infants in Puskesmas Mungkid Magelang. Descriptive analysis results showed the more the consumption of vitamin A that is getting enough milk to her baby. Research result consistent with research conducted by Anggraini \& Ika, 2018 which states that No relationship Early Initiation of Breastfeeding (IMD) with adequate production of breast milk (ASI) in mothers in BPM Mastuti, AMD.Keb District of Pardasuka District Pringsewu Year 2017 with a value of P-value = 0.002 and $\mathrm{OR}=35,000$ value. The more the baby suckles, the more milk production also his mother. Other than that mothers should breastfeed their babies with two breasts alternately so that the adequacy of breast milk for infants can be met.

\section{Conclusion And Suggestion.}

There was a significant association between vitamin A consumption and breasfeeding adequacy of postpartum mothers. Midwives are expected to provide health care and health education, regarding vitamin A for postpartum women, and give 2 capsules of vitamin $\mathrm{A}$ to the mother after delivery.

For postpartum mothers that after giving birth are suggested to obtain and consume 2 capsules of vitamin A, because the benefits are many, especially with the adequacy of breast milk to her baby. Further research need to expand the area of research and conduct in a longer period of time.

\section{References}

Adriani, M., \& Wijatmadi, B. (2012). Introduction to Nutrition Society.

Afifah. (2009). Giving suckle Early initiation and exclusive breastfeeding in Johan Pahlawan sub-district of West Aceh district.

Almatsier, S. (2010). Basic Principles of Nutrition.

Arikunto, S. (2006). Research Procedure A Practical Approach.

Bina, D., Nutrition, M., \& Department, K. (2009). Management Guide Supplementation of Vitamin A.

Puskesmas Bandung Sukawarna 2006. December period Shoulder Manado City Health Center. E Journal of Nursing (e$\mathrm{Kp}), 5$ (1), 1-7.

Hidayat, AA (2014). Midwifery Research Methods and Data Analysis Techniques.

Hitipeuw, AJ, As'ad, S., \& Mappawere, NA (2014). Giving the effectiveness of Vitamin A In Pregnancy Trimester III Against Breast milk production at Hospital Dr. M. Haulussy Ambon.

Marmi. (2014). Nutrition in Reproductive Health.

Muchtadi. (2009). Introduction to the Science of Nutrition.

Naibaho, E. (2011). Providing Vitamin A Capsule picture for Postpartum Mothers Helper Maternity By Tapanuli middle. Giving an overview Vitamin A 
Capsule For Postpartum Mothers Helper Maternity By Central Tapanuli.

Notoatmodjo, S. (2014). Health Research Methodology.

Peniston, Ashley, Valentine, \& Tanumiharjo, SA (2013). A Theoretical Increase in Infants Hepatic Vitamin A is supplemented lactating Reliazed Using a Model Sow.

Pitriani, R., \& Rika Andriyani. (2014). Mother Midwifery Care Ruling Normal (ASKEB III).

Purwanti, HS (2004). Applying the concept of exclusive breastfeeding Handbook

Wanayasa Banjarnegara district. Based on the characteristics of PHC Sukawarna mother in Bandung City Health Center Shoulder 2006 December period Manado. E Journal of Nursing (e-Kp), 5 (1), 1-7.

RI, D (2005). Acceleration guidelines Scope Capsules Vitamin A.

RI, D. (2009). IEC Strategy Guidelines Family Literacy Nutrition (Kadarzi).

Rini, S., \& F, K. (2016). Postpartum Care guide and Evidence Based Practice. Yogyakarta: Deepublish.

Riyanto, A. (2011). Application of Health Research Methodology.

Roesli, U. (2008). Early Initiation of Breastfeeding.

Regards, A., Dodik, B., Martianto, D., Ansul, RT, \& Arundhana, AI (2018). Vitamin A Supplementation Effect, Oil Fortification and Nutrition Education Capital Ruling against maternal and infant morbidity. Indonesia Media
Journal of Public Health, 14 (3), 214.

https://doi.org/10.30597/mkmi. v14i3.4348

Sari, EN, and Siti, K. (2018). Upbringing Kebidaan Mas Ruling And Breastfeeding.

Sediaoetama, A. (2010). Science of nutrition.

Setiawan, A., \& Saryono. (2011). Midwifery Research Methodology DIII, DIV,SI and S2.

Subekti, R. (2019). Proper Breastfeeding Techniques in the village Wanaraja, District

Journal of Research and Community Service UNSIQ, 6 (1), 45-49. https://doi.org/10.32699/ppkm. v6i1.550

Sugiyono. (2017). Statistics For Research.

Suherni, D. (2008). Care Postpartum Period.

Sujarweni, W. (2015). Statistics for Health.

Central, JAC (2008). Provision of High-Dose Vitamin A Capsule.

Usman, H. (2019). Combination Methods Woolwich and Massage Rolling Massage (back) Affects Breastfeeding On Capital Adequacy post partum in Puskesmas Mapane Poso district. Intelligent Midwives Journal, 2 (1).

Ward, RK, Nurmasari, W., \& Adriyan, P. (2018). Macro Nutrient Intake relationship Substances Breastfeeding and Nutrition Status With Macro Nutrient Substance Content On Mother's Milk (ASI) In Sub Bandarharjo Semarang. Journal Of Nutrition College, 3, 
360-367.

Waryana. (2010). Reproduction Nutrition.
Winarni. (2012). Pentingnya Vitamin A for Infants, Toddlers and Mrs. Ruling. 